Rev. Geol. Amér. Central, 10: 3 - 17, 1989

\title{
COSTA RICAN DIATOMITE: A REVIEW OF EXISTING KNOWLEDGE AND FUTURE POTENTIAL
}

\author{
Steve Mathers \\ British Geological Survey and \\ Dirección de Geología, Minas e Hidrocarburos \\ c/o Apartado 815 Centro Colón, 1007 San José, Costa Rica
}

\begin{abstract}
Existing information on diatomite in Costa Rica is compiled and reviewed. At present there are ten known occurrences of diatomaceous deposits, all occur in the northern half of Costa Rica, closely associated with late Tertiary (Pliocene)-Quaternary acid-intermediate volcanism. The most important known deposits are at Loma Camastro and Cañas Dulces in Guanacaste Province in northwestern Costa Rica where thick sequences $(>50 \mathrm{~m}$ ) of relatively pure diatomite have been reported, and provide resources estimated at over eight million metric tonnes. On this basis it is estimated that Costa Rica has at least $10 \%$ of the diatomite reserves of Central and South America.

Little data exist on the age, sedimentology and paleontology of Costa Rican diatomites. However available evidence indicates that they are of lacustrine origin. Promising avenues for research include $\mathrm{K}$-Ar dating of related volcanic rocks to provide limits for the age of the diatomites, detailed studies of the role of diatomite in lacustrine sedimentation in the tropics, systematic biostratigraphical studies, and a search for evidence of Quatemary climatic fluctuations within the diatomites.

About half of the world's production of diatomite is currently used in filtration, other major uses are as a functional filler, an absorbant and a mild abrasive. Future trends, including the development of synthetic filters and fillers and the retum to more traditional materials may cause a contraction in the overall diatomite market around the turn of the century. Hence Costa Rica should act quickly to exploit its reserves in order to maximise retum on this potentially valuable export commodity.
\end{abstract}

RESUMEN: Se analizan informes existentes sobre la diatomita en Costa Rica. En la actualidad se conocen diez depositos, todos asociados estrechamente al volcanismo ácido-intermedio del Terciario tardío (Plioceno)-Cuatemario. Los depósitos más importantes se ubican en Loma Camastro y Cañas Dulces, en la Provincia de Guanacaste. Estos gruesos depósitos de diatomita $(>50 \mathrm{~m})$ relativamente pura, proveen recursos estimados por encima de los ocho millones de toneladas métricas. Se estima que Costa Rica posee al menos el 10\% de las reservas conocidas de América Central y Sudamérica.

El origen de las diatomitas de Costa Rica es probablemente de agua dulce, sin embargo, existe poca información sobre su edad, sedimentología y paleontología. Fuentes prometedoras para la investigación en este campo incluyen: datos sobre $\mathbf{K}$-Ar para relacionar las rocas volcánicas y proveer límites de edad para la diatomita; estudios deta-llados del papel de la diatomita en la sedimentación lacustre de los trópicos; estudios sobre bioestratigrafía sistemática y un reconocimiento de las diatomitas para evidenciar las fluctuaciones climáticas del Cuaternario.

Alrededor de la mitad de la producción mundial de diatomita, es utilizada en técnicas de filtración. Otros usos importantes incluyen: aditivo rellenador, aditivo absorbente y abrasivo suave. Futuros cambios, como el desarrollo de filtros y rellenadores sintéticos, y el regreso a materiales más tradicio- 
nales, pueden causar una contracción del mercado de la diatomita. Por ello, Costa Rica debe actuar rápidamente para explotar sus reservas y no perder la valiosa oportunidad de exportar.

\section{INTRODUCTION}

The purpose of this review is to bring together all existing information on diatomite in Costa Rica. Much of this information has been hard to obtain and it is hoped that this compilation will save future academic and industrial workers considerable amounts of effort. This paper outlines very briefly, for the general reader, what diatomite is and how its uniqueness results in a wide variety of applications for processed diatomite powders. The general setting of the diatomite deposits within the late Tertiary (Pliocene)Quaternary volcanic terrain of Costa Rica is discussed and each known deposit is briefly described. Suggestions for future academic research and industrial development of the deposits are made in the context of present knowledge and world markets. Finally, a comprehensive bibliography is included for use as a starting point for future workers.

This paper forms part of a study by the Proyecto Anglo-Costarricense de Minerales Industrializables (PACOMI), a bilateral technical co-operation project between the governments of Great Britain and Costa Rica being implemented jointly by the British Geological Survey on behalf of the Overseas Development Administration and the Dirección de Geología, Minas e Hidrocarburos on behalf of the Ministerio de Recursos Naturales, Energía y Minas.

\section{DIATOMITE- GENERAL GEOLOGY}

Diatomite is a soft, pale-coloured, lightweight, siliceous sedimentary rock composed of the skeletal remains of diatoms-minute aquatic unicellular algac commonly $20-200 \mu \mathrm{m}$ in diameter. Diatoms precipitate a perforate cell wall of opaline silica to protect their soft organic interior, and upon death the organic material quickly decays leaving the siliceous skeletons to sink to the bottom of the watermass. Here they accumulate in vast numbers to form diatomaceous oozes which subsquently compact to form diatomite. The diatom skeleton, or frustule, is composed of two roughly equivalent overlapping valves. The shape of these valves enables classification into two principal types: the centric and pennate diatoms. The centric diatoms have circular valves, and are generally planktonic, immobile forms favouring marine habitats; whereas pennate diatoms have an elliptical shape, are mobile, and dominate most freshwater assemblages.

To enable substantial populations of diatoms to thrive several key environmental factors must be satisfied. (i) As primitive plants diatoms require light to photosynthesise and so they live within the shallow 'photic' zone of watermasses, generally at less than $35 \mathrm{~m}$ depth. (ii) In order to multiply rapidly diatoms require an abundant supply of soluble silica which they extract from the water for skeletal growth. In this context a close spatial relationship between acid-intermediate volcanism and many freshwater diatomites is well established since ash and other volcanic products such as tuffs, pumice and lavas provide an abundant supply of silica. (iii) Diatoms also need a steady supply of nutrients, principally phosphates, nitrates and iron, coupled with an absence of toxic substances and high concentrations of dissolved salts. Hence diatomites are not found as part of evaporite sequences. (iv) Many species have specific requirements of water temperature, salinity, $\mathrm{pH}$ and oxygen content. (v) For a relatively pure diatomite to accumulate a very low input of clastic material is essential, and subsidence is required for the deposition of thick sequences.

Diatoms live today in a wide variety of environments from the open ocean to nearshore; and in freshwater rivers, marshes and lakes. Their distribution ranges from polar to tropical latitudes, although in the oceans, sub-polar and temperate latitudes are preferred by many species.

Of about 10,000 known species many are extant and are diagnostic of distinct habitats, in fossil assemblages these same diatoms act as very 
good indicators of environment. Many of the extinct forms are used as zone-fossils which enable the age of marine strata to be determined accurately. As relatively simple forms of life diatoms probably have a long geological history although fossil evidence seems to indicate that they flourished markedly in the Cretaceous and have been abundant in Tertiary and Quaternary times. However, older diatom-rich deposits may be difficult to recognize in the stratigraphic record due to their conversion into chert by diagenetic processes. All commercially valuable diatomites are late Tertiary or Quaternary in age.

Diatomites are of variable purity, although the most commonly used commercial grades contain about $90 \% \mathrm{Si}_{2}$. The most common impurities comprise clay, volcanic ash, carbonate and organic material. In Denmark an impure (about $75 \% \mathrm{SiO}_{2}$ ) clay-rich diatomite called 'moler' is produced.

For further reading on general aspects of diatoms and diatomites the reader is referred to CONGER (1942), LOHMAN (1960) and BRASIER (1981).

\section{DIATOMITE - PROPERTIES, PROCESSING AND USES}

The uniqueness of diatomite lies in the structure of the diatom skeleton. The loosely-packed accumulation of these hollow, perforate skeletons results in a very lightweight sediment with a large proportion of interconnected voids. The opaline silica precipitated by the diatoms is softer than other forms of silica and is generally chemically inert. Consequent upon these basic characteristics are a series of properties which make diatomites of great value in a wide range of applications. These properties include high porosity and permeability, low density, high absorption, very large surface area, low abrasion, low thermal conductivity and moderately refractory behaviour.

Diatomite, as dug, may contain at least $50 \%$ water by weight. The main aims of processing are to remove most of this water, to grind the material to the required size, and to remove the impurities. In tropical countries removal of the water can often be partly achieved by spreading the dug diatomite out to dry in the sun. This results in a substantial saving of energy costs and a cheaper end-product.

The diatomite is then simultaneously milled and dried. In order to preserve the delicate skeletal structure of the diatoms, milling is normally accomplished using spiked or ribbed rollers, rathet than more conventional methods. Separation of the impurities and air from the dried powder is then achieved by a series of separators and cyclones producing the required dry diatomite powder.

If a very specific size distribution is required, as is commonly the case with filter-aids, the diatomite may be subsequently fired (calcined) in a rotary kiln at about $1000^{\circ} \mathrm{C}$. The partial melting results in strengthening and particle aggregation enables the powder to be re-milled to the required size. The addition of flux (flux-calcination) helps the aggregation process and prevents the oxidation of iron impurities which can give the endproduct a pinkish colouration. Even more specific treatments have been developed for diatomite powders that are used, for example, as chemical supports.

Diatomite powders have a wide range of uses and the following account gives only a very brief outline, for more detailed information the reader is referred to the accounts by KADEY (1983) and ANON (1987). The principal uses of diatomite are as a filter-aid, a filler, an absorbant, a mild abrasive and an insulator. Each use utilizes specific properties or combinations of properties of the diatomite powder.

Processed diatomite used as a filter aid accounts for about $50 \%$ of world diatomite production, the main markets are in the U.S.A. and Europe. The powder is used in two ways, either as a layer supported by a cloth screen through which the filtrate passes, or by direct addition to the liquid where the powder sinks through the liquid trapping fine particles. Fluids commonly clarified include wine, beer, swimming pool waters, cleaning solvents, pharmaceuticals, foodstuffs and varnishes.

The diatomite powders used in filtration commonly contain about $90 \%$ voids leading to excellent permeability. The small size of the bassagewavs and openings in the diatom skele- 
tons enables very fine particles to be trapped, and the chemical inertness of the diatomite is essential preventing reaction and possible contamination of the filtrate.

Diatomite powders are also utilized extensively as fillers in products such as paint, plastics, rubber and chemicals. In the majority of cases the diatomite is added to improve properties of the host material - as a functional filler - rather than just to extend its bulk. For example, in paint the addition of diatomite powder is believed to roughen the paint film and aid adhesion. In toothpaste and polishes the mildly abrasive properties of diatomite are beneficial.

The absorptive properties of diatomite powders, often two or three times their own weight, results in their use as "carriers" of liquids to perform specific functions. For example, dangerous chemicals can be stored much more safely by impregnation into diatomite powders; and diatomite granules carrying agrochemicals can also aid uniform dispersal and slow release of the liquid. Diatomite powder is also used in sanitary pet-litter where its absorptive qualities and ability to prevent odours are utilized.

Diatomite is also used as an anti-caking agent such as in the coating of fertilizer pellets to help prevent them absorbing moisture and sticking together. Impure 'moler' products have been principally used in the manufacture of insulating bricks, in which the low thermal conductivity of the diatomite is a key property.

\section{PRESENT MARKETS AND FUTURE TRENDS}

World diatomite production has risen steadily in recent years to a level in 1986 of just short of 1.8 million metric tonnes per annum. The United States accounts for almost a third of world production, principally in the states of California, Nevada, Washington and Oregon. Other major producers are Romania, the U.S.S.R., France and Denmark (mainly 'moler'). Small producers account for $20 \%$ of the production. Most of the industrial nations of Europe, together with Canada, South Africa, Japan, Australia and Saudi Arabia, import substantial amounts of processed diatomite. The principal exporters are the U.S.A. (about $50 \%$ world exports), Denmark (mainly 'moler' and 'moler' bricks) and to a lesser extent Iceland and Mexico.

World reserves of diatomite have been estimated at about 800 million short tons $(=\mathrm{ca} .700$ million metric tonnes) with a reserve base of 2,000 million short tons $(=$ ca 1,800 million metric tonnes),(MEISINGER, 1985). The United States possesses about $25 \%$ of these reserves and European countries about $50 \%$.

Continued growth averaging about $3 \%$ per annum is expected in diatomite production until the end of the century (ANON, 1987). However, decreases are forecast in the consumption of diatomite in filtration and as a filler (KADEY, 1983; ANON, 1987) as synthetic alternatives are developed and some industries consider returning to more traditional technology such as the use of sand filters (e.g. HERD, 1988). If diatomite consumption is unable to expand in its other uses there may be a stagnation of the presently rising demand.

\section{COSTA RICAN DIATOMITE}

\section{Geological Setting}

To date there are ten reported occurrences of diatomite in Costa Rica (Fig. 1). All these deposits occur in the northem half of Costa Rica and are closely associated with late Tertiary (Pliocene)Quaternary volcanism (Figs. 1, 2).

This volcanic terrain has been divided into four units by LUDDINGTON et al. (1987).

1) The proximal volcanic deposits comprising a northwest-southeast aligned chain of stratovolcanoes principally comprising lavas, ash-flows. and lahars. These deposits include the Monteverde formation sensu CHAVES and SAENZ (1974) which is probably Lower Pleistocene in age (G. ALVARADO work in progress). Diatomite is commonly associated with these deposits.

2) The extensive flat-lying terrain formed by a series of ash-flow tuff sheets flanking the stratovolcanoes on their southwest side between the Nicaraguan border and Cañas. These ash-flow tuff deposits were originally divided on the basis of colour into the Bagaces and Liberia formations (DONDOLI, 1950; DENGO, 1962) however 


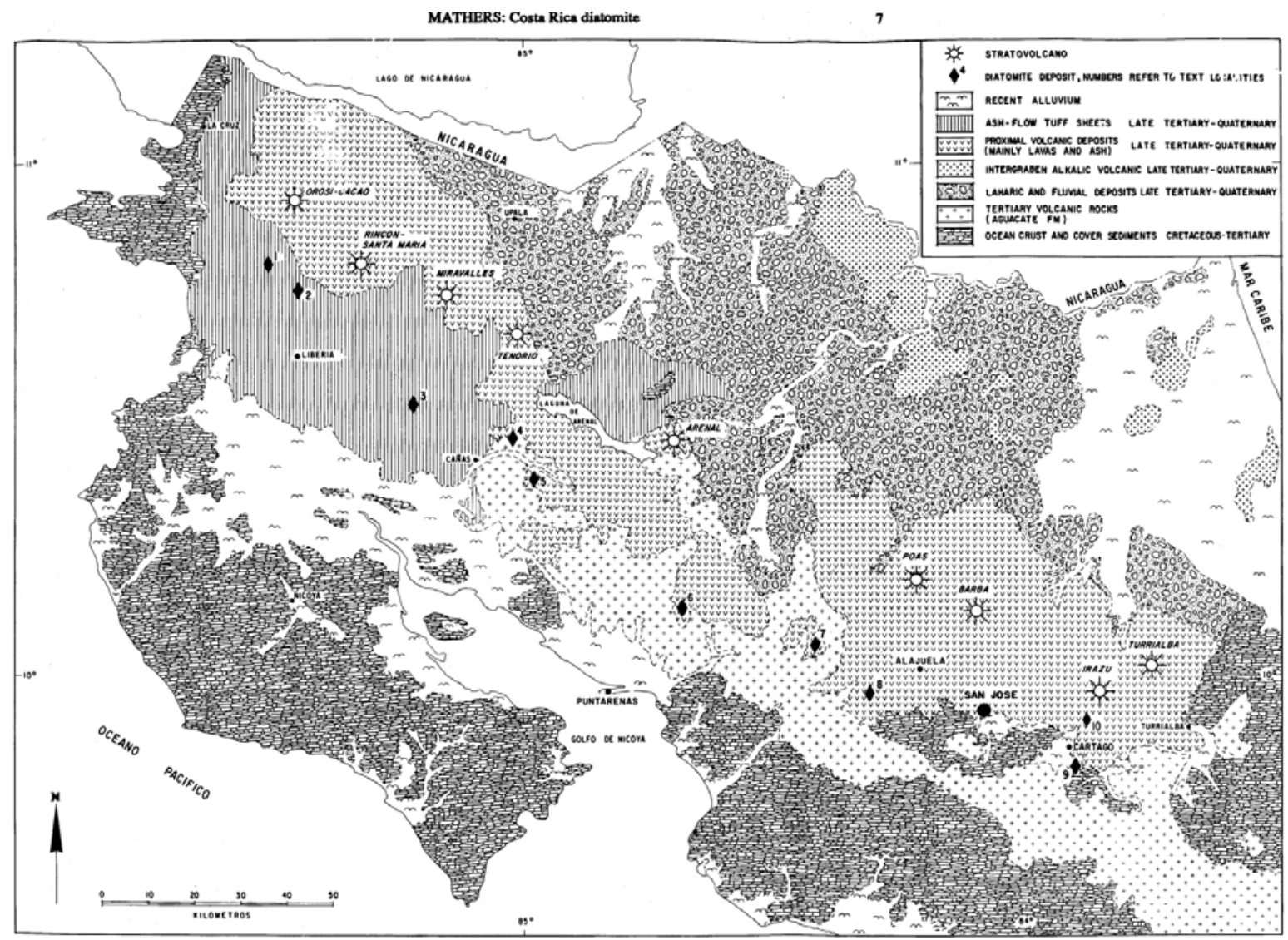

Fig. 1: Geology of northwest Costa Rica showing the location of diatomaceous deposits. - 1.= Loma Camastro, 2.= Cañas Dulces, 3. $=$ Montano de Bagaces, 4, $=$ Los Angeles, $5,=$ Libano, $6,=$ Peñas Blancas, $7 .=$ Palmares, $8=$ Turrucares, 9, = Agua Caliente, 10.= Llano Grande 


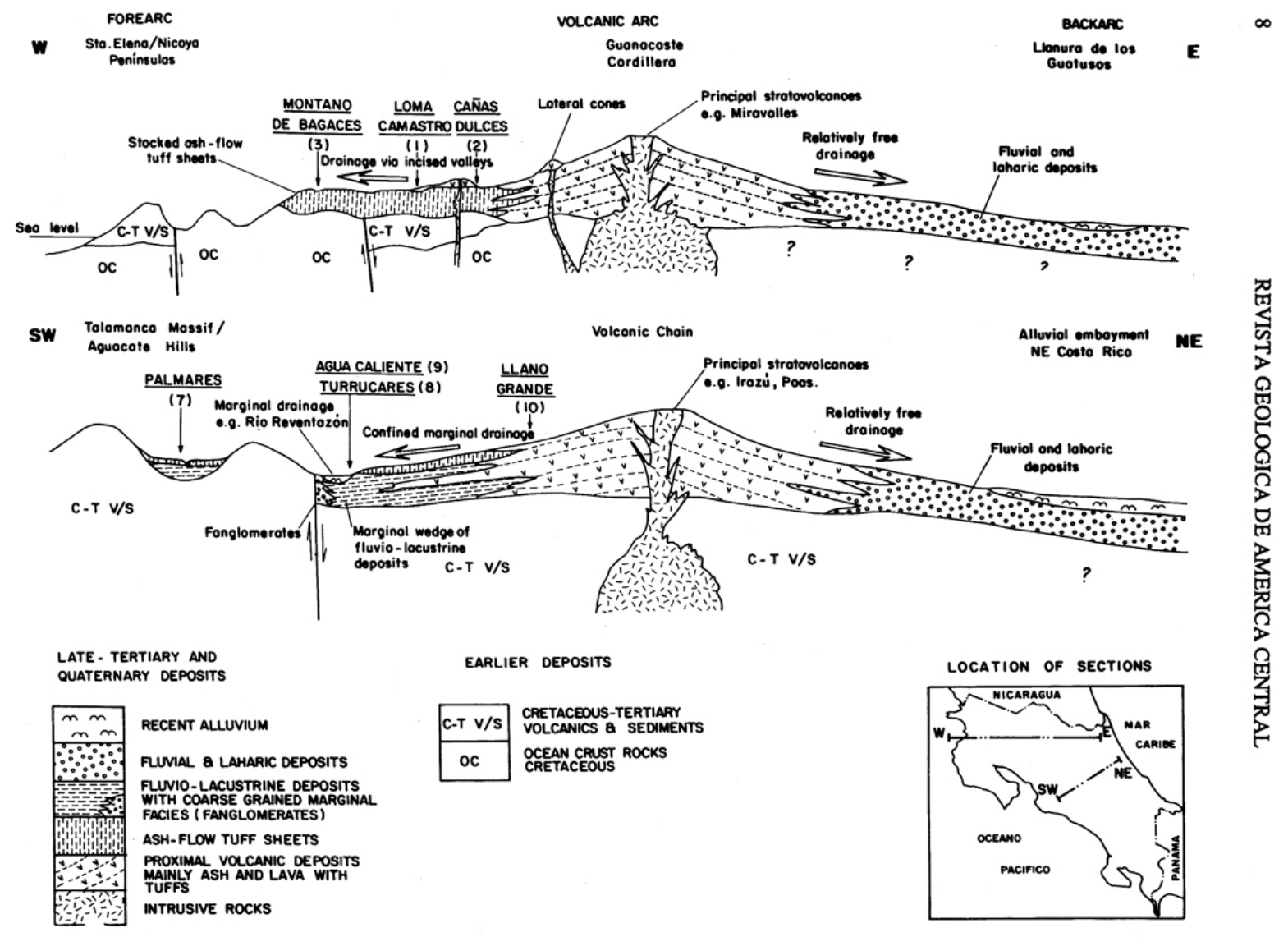

Fig. 2: Schematic cross-sections showing the location of diatomite deposits. 
difficulties in distinguishing the two led KUSSMAUL and SPRECHMANN in SPRECHMANN (1984) to group all the deposits under the heading Bagaces Formation. More recent detailed studies of the petrography, distribution and stratigraphy of these predominantly pyroclastic sediments has revealed the presence regionally of up to 15 distinct ash-flow tuff sheets (CHIESA et al., 1987; MORA, O., oral communication). Palaeosol horizons commonly separate these units as do intercalated fluvial and lacustrine sediments including diatomites.

3) On the northwest flank of the stratovolcanoes 'distal' volcanic deposits have been identified which principally comprise laharic deposits. Little work has been done on these sediments and no diatomite deposits have been reported associated with them.

4) Intergraben volcanics comprising alkalic lavas and pyroclastics in northern and northeastem Costa Rica; these deposits are not known to be associated with diatomite and are not considered further here.

All the known occurrences of diatomite lie on the southwest side of the volcanic chain within the proximal volcanic terrain, the ash-flow tuff sheets or within lacustrine basins at or near the edge of the late Tertiary-Quaternary volcanic deposits (Fig. 2).

The known distribution of diatomite in Costa Rica may be accounted for by human, climatic or geological factors, or possibly a combination of factors. The reason for the apparent concentration on the southwest flank of the volcanic range may be due to the fact that this side has probably been more densely populated and less densely forested, thereby leading to an increased likelihood of deposits being encountered. Diatomite deposits may well be found on the northeast side of the stratovolcanoes as this area is developed. It is interesting to note that several rivers where diatomite occurs in Costa Rica are named "Rio Tizatl" which is the pre-Colombian Nahuatl name for chalk which the diatomite resembles. The name is still used by many rural dwellers and so it seems that many of the diatomites were discovered many centuries ago.

The difference in volcanic facies on either side of the volcanic chain may have made condi- tions more favourable for diatomite deposition on the southwest flank; or the extensive series of laharic deposits to the northeast רsav well have buried diatomite-rich sequences.

The listed occurrences of diatomita. ere thought to be exclusively lacustrine in origin. 'nll a close relationship of all the deposits with terres? trial volcanics, their altitudes which range up to 2,300 $\mathrm{m}$ above sea-level, their occurrence witrin । sequences interpreted as lacustrinc'oe dirubersiosf sedimentary faunal and floral evidence (ALVARADO, 1986) and the limited palaeontological evi: dence (Table 1), all clearly point to a freshwater rather than a saltwater origin. Landscapes of active vulcanicity are continually changing their morphology, the rivers are frequently impounded by lavas, lahars and ash-flows producing lakes in which diatoms can thrive. The principal sediment-forming processes likely to be encountered in these lacustrine basins are shown in Fig. 3 .

Similar Plio-Pleistocene diatomite-rich deposits have also been described from El Salvador where the lacustrine deposits contain fossil frogs, fish and abundant plant material. The flora from these sediments is similar to present-day vegetation in the region and so gives no indication of climatic changes during the Quaternary. (LÖTSCHERT \& MÄDLER, 1975; SCHMID T-THOMÉ, 1975; SEIFFERT, 1977). In addition, freshwater diatomite-rich lacustrine deposits of PlioPleistocene age are reported throughout the Western Cordillera of North America and along the Andean chain in close association with acidintermediate volcanism, in Canada, Western U.S.A., Mexico, Guatemala, Colombia, Ecuador, Peru, Bolivia and Chile (TALIAFERRO, 1933; MULRYAN, 1942; SERRANO, 1960; WILLIAMSON, 1966; KADEY, 1983). In Costa Rica there are no reported occurrences of diatomite from the somewhat older, but compositionally similar volcanics of the Tertiary Aguacate Formation (Fig. 1). However, these volcanics have experienced a long history of mineralisation, hydrothermal alteration and tectonic movements which might have diagenetically altered any associated diatomite deposits.

The local geology of some of Costa Rican diatomite occurrences has been established by the investigations undertaken by the Corporación 


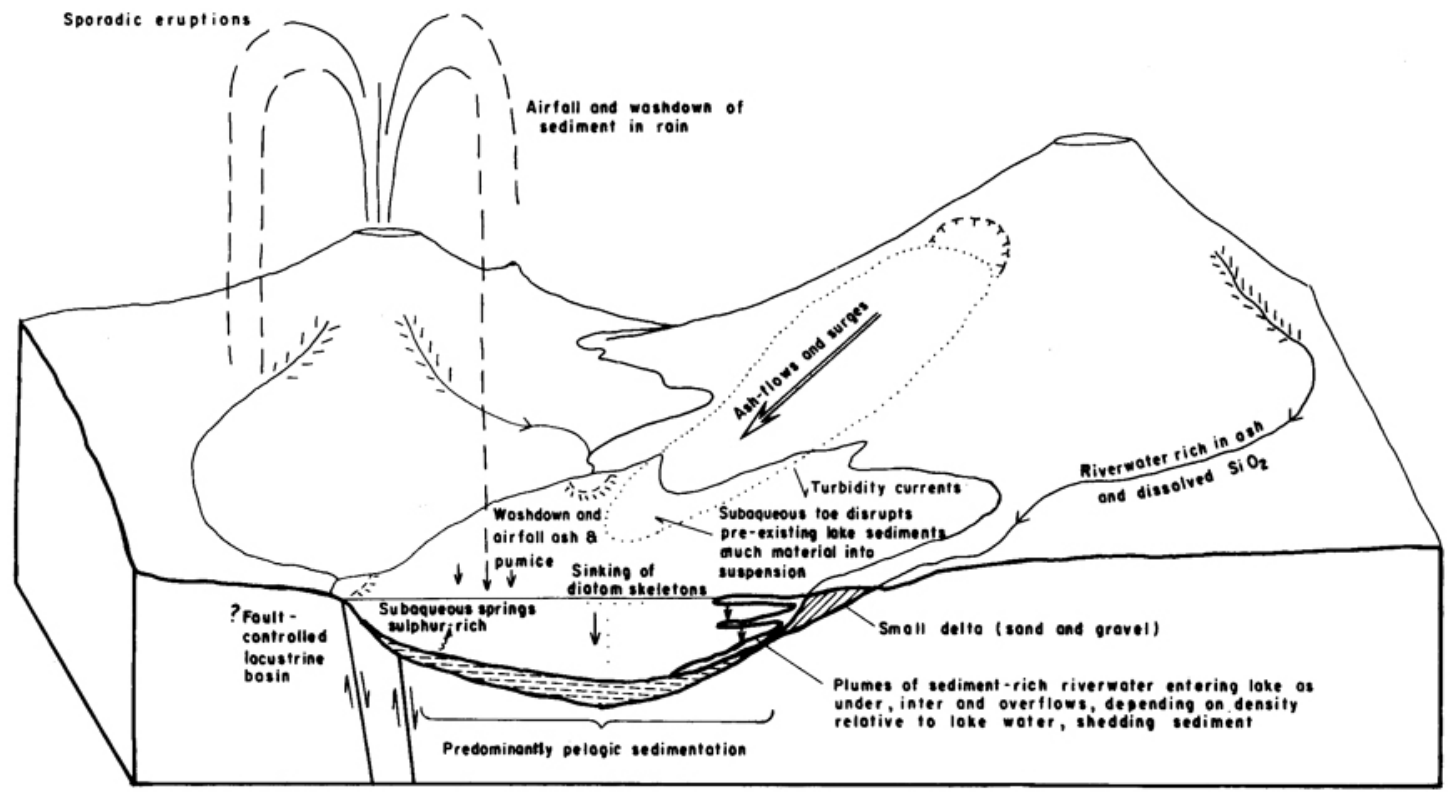

Fig. 3: Principal processes contributing sediment to lake basins.

TABLE 1:

FOSSIL DIATOM IDENTIFICATIONS

\begin{tabular}{|c|c|c|c|c|}
\hline $\begin{array}{l}\text { Montano de Bagaces } \\
\text { (Sandoval \& Brenes } \\
\text { (1967) }\end{array}$ & $\begin{array}{l}\text { Cañas Dulces } \\
\text { (Segura, 1945; } \\
\text { \& Fisher, pers. } \\
\text { comm. in. } \\
\text { Salazar, 1978) }\end{array}$ & $\begin{array}{l}\text { Loma Camastro } \\
\text { (Fisher, pers. } \\
\text { comm. in } \\
\text { Salazar, 1978) }\end{array}$ & $\begin{array}{l}\text { Turrúcares } \\
\text { (Segura, } 1940 \\
\text { Lohman reported } \\
\text { by Madrigal, } 1960 \\
\text { \& by Sandoval, } \\
\text { 1966) }\end{array}$ & $\begin{array}{l}\text { Barra Morado } \\
\text { (Segura, } 1940 \\
\text { illustrated } 43 \\
\text { species inclu- } \\
\text { ding the follo- } \\
\text { wing identifica } \\
\text { tions) }\end{array}$ \\
\hline $\begin{array}{l}\text { Nitzshia } \\
\text { scalaris } \\
\text { Epithemia } \\
\text { hyndnannii } \\
\text { Clemacosphenia } \\
\text { elongata } \\
\text { Melosira } \\
\text { arenaria } \\
\text { Coscinodiscus sp. } \\
\text { Odentodiscus sp. }\end{array}$ & $\begin{array}{l}\text { Melosira } \\
\text { ? granulata } \\
\text { Epithemia } \\
\text { sp. } \\
\text { Gomphonema } \\
\text { sp. }\end{array}$ & $\begin{array}{l}\text { Gomphonema } \\
\text { sp. } \\
\text { Epithemia } \\
\text { sp. }\end{array}$ & $\begin{array}{l}\text { Navicula } \\
\text { peregrina } \\
\text { Polymysus } \\
\text { coronalis } \\
\text { Amphora } \\
\text { sp. } \\
\text { Cocconeis } \\
\text { sp. } \\
\text { Epithemia sp. } \\
\text { Gomphonema sp. } \\
\text { Tholipidia } \\
\text { sp. } \\
\text { Rhopalodia sp. } \\
\text { Stephanodiscus sp. } \\
\text { Melosira sp. } \\
\text { Cyclotella sp. }\end{array}$ & $\begin{array}{l}\text { Stauroneis } \\
\text { phoenicenteron } \\
\text { Cymbella } \\
\text { lanceolata } \\
\text { Pinularia } \\
\text { major } \\
\text { Melosira } \\
\text { gramulata } \\
\text { Gomphonema sp. } \\
\text { Eunotia sp. } \\
\text { Varius centric } \\
\text { forms }\end{array}$ \\
\hline
\end{tabular}


Costarricense de Desarrollo (CODESA) and the Dirección deGeología, Minas y Petróleo(DGMP) now DGMH at Loma Camastro and Cañas Dulces (SALAZAR, 1978), Montano de Bagaces (SANDOVAL \& BRENES, 1967) and at Turrúcares(SANDOVAL, 1966). A short review of Costa Rican diatomite was published by MADRIGAL (1960).

To date diatomite is known to have been commercially extracted at Montano de Bagaces, Loma Camastro, Cañas Dulces, Los Angeles, Turrúcares and Líbano. The principal use of the material has been as an anti-caking agent in the production of fertilizers by FERTICA S.A. Feasibility studies are believed to be in progress to assess the use of the deposits as a filter-aid for local and export markets.

\section{DEPOSITS}

The following account gives brief details of the occurrences identified in Fig. 1. Each site is given together with its grid reference on the National 1:50 000 scale topographic maps.

\section{Loma Camastro}

This site [373-310], on Ahogados and Curubandé map sheets was originally mentioned by SEGURA (1945), subsequently investigated in detail by SALAZAR (1978) and evaluated economically by LACAYO \& SOTO (1978). The diatomite deposits at Loma Camastro occur within a $+100 \mathrm{~m}$ - thick ?fluvial and lacustrine sequence which infills a basin of at least $5 \mathrm{~km}^{2}$. The diatomite forms the upper part of the sequence in the northern part and has been estimated to be locally $80-100 \mathrm{~m}$ thick. The associated deposits comprise stratified sands and silts with thin beds of diatomite.

The lacustrine sequence rests on an ash-flow tuff and is partly overlain by an andesitic lava. Generally the lacustrine strata have dips of less than $10^{\circ}$ that are largely original. Photogeological evidence of lineaments and local steepening of the dips, probably due to drag-folding, suggests that the deposits are faulted.

A provisional estimate (SALAZAR, 1978) of the volume of diatomite at Loma Camastro -
5.8 million metric tonnes indicates that this occurrence is the largest known in Costa Rica and economically can be considered to be of international importance.

\section{Cañas Dulces}

The Cañas Dulces diatomite deposits, [379305] on Curubandé map sheet were initially mentioned by SEGURA (1945), discussed by MADRIGAL (1960), investigated in detail by SALAZAR (1978), and evaluated economically by LACAYO \& SOTO (1978).

The Cañas Dulces area is floored by an ashflow tuff unit overlain around Cañas Dulces by andesite lavas probably relating to a local volcanic centre. The diatomite deposits infill a roughly circular depression $\left(0.25 \mathrm{~km}^{2}\right)$ along the eastern margin of the lavas. Surface outcrops indicate the diatomite locally contains waste lenses of ash up to $5 \mathrm{~m}$ thick. Estimates, based on surface information only, suggest that there is up to $70 \mathrm{~m}$ of diatomite infilling the depression, yielding an overall volume of 2.43 million metric tonnes. A chemical analysis of diatomite from Cañas Dulces is reported by SEGURA (1945), more detailed investigations were carried out by ARAYA (1963). Based on the latter the main physical properties of the diatomite were summarized by SALAZAR (1978, p. 319).

\section{Montano de Bagaces}

The diatomite at Montano de Bagaces [405278] on Tierras Morenas map sheet was investigated in detail by SANDOVAL \& BRENES (1967). The survey included geological mapping and drilling. Around Montano a series of small hills contain erosional remnants of a lacustrine sequence infilling a lake basin with a possible original size of between $1-1.5 \mathrm{~km}^{2}$. These lacustrine sediments and interbedded volcanics are locally up to $15 \mathrm{~m}$ thick in hill $\mathrm{N}^{2} 1$ (sensu SANDOVAL \& BRENES, 1967) just northwest of Montano the diatomite forms the upper part of this sequence, varying from $0-7 \mathrm{~m}$ in thickness with an average of $4 \mathrm{~m}$. The diatomite overlies an ash-flow tuff which incorporates large blocks of diatomite several metres across indicating dis- 
ruption of initial diatomite deposits on the lake bed prior to the sedimentation of the overlying undisturbed diatomite. SANDOVAL \& BRENES (1967) estimated the volume of diatomite to be $32,700 \mathrm{~m}^{3}$ (about 23,000 metric tonnes) the majority of which was worked out in the 1960's and used as an anti-caking agent for fertilizers. A single chemical analysis of the diatomite is given in SANDOVAL \& BRENES (1967, p. 18).

\section{Los Angeles}

The Los Angeles diatomite deposits [424272] on the Canfas map sheet were identified during the advanced reconnaissance study for the Corobicí hydroelectric project (UMAÑA, et al., 1975). They comprise a small lenticular valleyside outcrop along the Río Santa Rosa within a volcanic sequence.

The diatomite forms a lens 5-8 $\mathrm{m}$ thick between a basal ash-flow tuff and an overlying 100 $\mathrm{m}$ thick lava sequence (informally termed "lavas hojosas de Tierras Morenas" sensu UMAÑA et al., 1975) and possibly equivalent to the Monteverde Formation (G. ALVARADO oral communication). These lavas are locally overlain by extrusive materials from the nearby Cerro Concepción cinder cone of Quaternary age whose deposits are well exposed in the quarry known as Tajo Chopo adjacent to the Canfas-Tilarán road (MORA, 1977). The length of the diatomite outcrop is not certain but it probably stretches for at least $0.75 \mathrm{~km}$. A small quarry was opened in the deposits and the material used as an anti-caking agent, but extraction was limited because of the presence upslope of substantial overburden. The diatomite is finely laminated with thin interbeds of sand and ash. The sequence is gently folded and faulted, possibly due in part to loading by the thick overlying lava pile.

\section{Líbano}

Two small deposits of diatomite are known from the area to the south of Líbano. a) On the road to San José, [4293-2644] Tilarán map sheet, a small occurrence is known on the southern side of the Río San José valley below the house of Sr. Rodríguez some $2 \mathrm{~km}$ southwest of Líbano.
Preliminary investigations were carried out bul the deposit was not subsequently exploited. There are no surface exposures. b) Just over a kilometre to the west, [4283-2640] Tilarán map sheet, a further occurrence is known on the farm owned by the Gómez family. Small-scale extraction has taken place and quarry sections reveal 2-3 m of diatomite overlain by a similar thickness of talus and weathered material. The diatomite dips at up to $60^{\circ}$ in the quarry and contains thin interbeds $(<$ $20 \mathrm{~cm}$ ) of clay.

\section{Peñas Blancas}

The Peñas Blancas deposit [462-234] on Miramar map sheet, first mentioned by MADRIGAL (1960), is located on the farm of Sr. González atPeñas Blancas. A lacustrine sequence some 25$30 \mathrm{~m}$ thick overlies thick pyroclastic ash-flow tuffs. MADRIGAL (1960) reports $3 \mathrm{~m}$ of diatomite at the base of the lacustrine sequence although a recent field inspection by the author suggests this may be an underestimate. Of note is the particularly well developed fine rhythmic lamination in the deposit which may reflect annual patterns of sedimentation analogous to those forming varves in glacial lake deposits. The extent of this deposit is unknown, and as it is located on a steep densely wooded valley side about a kilometre from the nearest road it would be difficult to develop. The site also lies within the Refugio de Fauna y Vida Silvestre de Peñas Blancas placing very tight environmental controls on any possible development. Extraction at this site would also be difficult due to the substantial overburden present. Dry samples from this site have a specific gravity of $0.7 \mathrm{~g} / \mathrm{cm}^{-3}$ (MADRIGAL, 1960).

\section{Palmares}

A large former lake basin (ca $50 \mathrm{~km}^{2}$ ) was developed in the Palmares [489-227]-San Ramón [485-230] area, on the Naranjo map sheet, and persists today as a depression within the volcanic terrain formed by the Aguacate Formation of Tertiary age (DONDOLI, 1951; VARGAS, 1976; RODRIGUEZ, 1976). Within this basin a thick sequence (up to $90 \mathrm{~m}$ ) of lacustrine sediments with beds of diatomite were deposited. and over- 
lain by an ash-flow tuff and locally by talus deposits. On the basis of a compilation of palaeontological data, ALVARADO (1986) tentatively assigned these lacustrine deposits to the Lower Pleistocene.

The draining of the lake was finally achieved via the impressive canyon of the Río Grande which flows eastwards, the subsequent deep incision by rivers within the basin has produced valley-side sections where the sequence can be examined.

In surface exposures the lacustrine sediments principally comprise sands, silts, clays and waterlain volcaniclastic deposits. Diatomite beds are known from two localities.

(i), DONDOLI (1951, p.8) presentsagraphic $\log$ of the sequence in the Quebrada Grande near Candelaria which contains thin beds of diatomite, and although their actual thickness was not reported they are probably less than $0.5 \mathrm{~m}$ thick.

(ii), roadside exposures [4891-2293] on the Inter-American Highway reveal the presence of a bed of ca $1.5 \mathrm{~m}$ of finely laminated diatomite within the lacustrine sequence.

These two occurrences give hope to the idea that there might be economic diatomite deposits within the basin. However, the majority of the exposures of lacustrine deposits do not contain any diatomite and test drilling of parts of the basin have revealed no substantial deposits (R. RODRIGUEZ oral communication). Whilst diatomite may yet be worked from the Palmares-San Ramón basin, present evidence suggests the chances are small.

\section{Turrúcares}

Diatomite deposits are also known to infill a second lake basin in the San Miguel de Turrúcares area [501-216] on the Río Grande map sheet (MADRIGAL, 1960; SANDOVAL, 1966; BRENES, 1967; MONTERO, 1975). These deposits are thought to be broadly equivalent in age to those of the Palmares-San Ramón basin (ALVARADO, 1986). The deposits crop out over an area of approximately $1 \mathrm{~km}^{2}$ around San Miguel de Turrúcares (see MONTERO, 1975), elsewhere they are buried beneath late Pleistocene and Recent ash-flow tuffs, lavas and ashes (BRENES, 1967).
Detailed investigation of the San Miguel de Turrúcares area (SANDOVAL, 1966) included the drilling of 16 boreholes to depths of up to 76.2 $\mathrm{m}$ to assess the diatomite potential of the lacustrine sequence. Hereabouts, the volcanic rocks of the Tertiary Aguacate Formation are overlain by up to $50 \mathrm{~m}$ of lacustrine deposits within which three units can be recognized. The basal unit comprises about $35 \mathrm{~m}$ of waterlain volcaniclastics and is overlain by a middle unit averaging 5 $\mathrm{m}$ thick of interbedded diatomite and volcaniclastics. The upper unit comprises more volcaniclastics and is generally about $15 \mathrm{~m}$ thick. This sequence is capped by an ash-flow tuff about 10 m thick.

The diatomite-rich unit varies in thickness from $0.5-10.0 \mathrm{~m}$ with diatomite beds up to $1 \mathrm{~m}$ thick separated by laminae and thin beds of volcaniclastics. The deposits are reported to contain locally 2-3\% 'oil' (SEGURA, 1940). Detailed calculations of the volume of the diatomite (SANDOVAL, 1966), indicate nearly 440,000 $\mathrm{m}^{3}$ (assuming a dry density of about $0.7 \mathrm{~g} / \mathrm{cm}^{-3}$ this gives about 300,000 metric tonnes of material).

A quarry was opened in the 1970's along the outcrop of the diatomite-rich beds on the farm $\mathrm{Sr}$. Hernández south of Turrúcares. Much fossil material principally of plants and fish was recovered from this site. Several excellent specimens of freshwater fish belonging to the Family Cichlidae are included in the collections at the National Museum (Specimen N ${ }^{\text {s }}$ CFM 278, 279) and at the University of Costa Rica where one specimen has been designated CichlasomaTurrúcarensis by Dr. P. Sprechmann.

The substantial overburden to deposit ratio (generally about 5:1) and the difficulties of extracting and processing a finely interbedded sequence of diatomite and waste, will probably preclude further exploitation of this deposit.

\section{Agua Caliente}

Thin beds of diatomite have been reported in association with lacustrine deposits from the sides of the Agua Caliente valley [around 548-202] Tapantí map sheet. These lacustrine deposits are related to blocking of the proto-Agua Caliente 
river and impounding of its drainage (DONDOLI, 1954). An outcrop near Barro Morado is described by MADRIGAL (1960) where $8 \mathrm{~m}$ of lacustrine deposits include about $1 \mathrm{~m}$ of diatomite. The palaeontology of these deposits is described by SEGURA (1940) who also reports an Specific Gravity for the deposit of 2.0-2.2 g/ $\mathrm{cm}^{-3}$. The diatomite deposits appear to be too thin to be of economic value.

\section{Llano Grande}

A small outcrop [5464-2140] of diatomite, on the Istarú map sheet, has been reported from a quarry owned by Ricalit S.A. near Llano Grande (ALVARADO, 1983; GARCIA\& ALVARADO, 1984; RODRIGUEZ, 1984). The lenticular deposit has an extension of $50 \mathrm{~m}$ and a maximum width of $10 \mathrm{~m}$.

\section{PRODUCTION AND DEMAND}

Costa Rica is estimated to produce about 4,500 metric tonnes of processed diatomite annually, all of which is used for the domestic market, principally as an anti-caking agent in fertilizers. In addition Costa Rica imports between 200-400 metric tonnes annually, for use in filtration and as a functional filler. Costa Rica probably possesses about $1 \%$ of the world's known resources of diatomite and possibly as much as $10-20 \%$ of the resources of Central and South America.

\section{FUTURE RESEARCH}

The diatomite of Costa Rica has to date received very little attention from academic workers. Several major questions can be posed for solution:

a) What is the age or age range of the various diatomite deposits?

b) What are the mechanics and rates of sedimentation of diatomaceous deposits in tropical lakes?

c) What is the stratigraphical and spatial variation of the diatom assemblages?

d) Do these lacustrine sequences contain biostratigraphical evidence for climatic fluctations during the late Tertiary-Quaternary?
In order to establish the age(s) of the diatomite the most useful technique is likely to be $\mathrm{K}$-Ar isotope dating of lavas and tuffs which underlie and overlie diatomites, thus providing broad limits on the age of diatomite sedimentation. Assuming an average sedimentation rate of about $0.5 \mathrm{~mm} /$ year (SOPER \& OBSON, 1922; WILLIAMSON, 1966) the thickest Costa Rican deposits (reportedly $+50 \mathrm{~m}$ at Loma Camastro and Cañas Dulces) would have been sedimented over a period of ca 100,000 years. Some of the sequences contain fine rhythmically laminated diatomite which may well reflect annual varvelike sedimentation. Annual non-glacial varves have been observed in diatomite- rich deposits (e.g. KELTS \& HSÜ, 1978) in temperate latitudes. However, the hydrodynamics of tropical lakes are likely to be different since the nearsurface water temperature remains more constant throughout the year whereas in temperate lakes it varies markedly leading to overturning of the watermass in the autumn due to rapid cooling of the surface waters. The rhythmic lamination seen in Costa Rican diatomites may reflect variable clastic input during the wet-dry season cycle.

Detailed studies of the diatom assemblages will no doubt reveal further information about the lacustrine environments and differences between individual occurrences. The assemblages are unlikely to yield accurate information on the age of the deposits.

However, studies of the pollen and diatoms, together with sedimentological data, may well be able to identify oscillations of climate which characterize the late Tertiary-Quaternary time span. In this context however, no evidence of floral change was discovered in the diatomite sequence from the Río Sisimico, the late TertiaryQuaternary Cuscutlán sequence in El Salvador (LÖTSCHER \& MÄDLER, 1975).

In addition to the above possibilities, the systematic detailed mapping of the diatomite occurrences is needed to demostrate the local stratigraphical relationships.

\section{CONCLUSIONS}

1) Costa Rica possesses good quality diatomite reserves estimated at over 8 million me- 
tric tonnes, these probably constitute $10-20 \%$ of the known reserves of Central and South America.

2)The principal sites of importance are Loma Camastro and Cañas Dulces in Guanacaste Province although other important reserves are likely to be discovered.

3) About 4,500 metric tonnes of processed Costa Rican diatomite is currently utilized each year, as an anti-caking agent for coating fertilizer pellets, manufactured by FERTICA S.A. at Puntarenas.

4) Costa Rica imports on average $200-400$ metric tonnes of diatomite for use in filtration, this market is worth at least US $\$ 100,000$ a year and could be supplied by the development of a plant to produce diatomite of filter-aid grade in Costa Rica.

5) Since world demand for diatomite as a filter-aid may cease to grow around the end of the century, it is appropiate that Costa Rica also tries to export some of its diatomite over the next 1015 years otherwise the opportunity to profit from these valuable reserves may be missed.

6) Costa Rican diatomite deposits offer considerable potential for research especially in the fields of sedimentology, palaeontology and Quaternary studies.

\section{ACKNOWLEDGEMENTS}

The author wishes to thank Dr.J.P. Berrangé, A. Salazar, N. Morales, G. Alvarado, R. Rodríguez and F. Alvarado for helpful discussions on various aspects of this paper. This paper is published with the permission of the Director of the British Geological Survey (Natural Environment Research Council).

\section{REFERENCES}

ALVARADO, F., 1983: Geología, evaluación y planeamiento de explotación preliminar. - Cantera de diatomita propiedad de Ricalit S.A., Llano Grande de Cartago, Industria Nacional de Cemento S.A. San José. (unpublished report).

ALVARADO, G.E., 1986: Hallazgos de megamamíferos fósiles en Costa Rica. - Rev. geol. Amér. Central, 4: 1-46.
ANON, 1987: Diatomite-no skeletons in the cupboard. - Industrial Minerals, 236: 22-39.

ARAYA, J.A., 1963: Estudio sobre el aprovechamiento industrial de la diatomita de Liberia. - 88 págs. Escuela de Química, Universidad de Costa Rica (tésis inédita).

BRASIER, M.D., 1981: Division Chrysophyta-Diatoms in Microfossils. - Allen \& Unwin, London: 39-44.

BRENES, M.A., 1967: Contribución a la geología del Valle Central occidental.- Facultad de Agronomía, Universidad de Costa Rica (tésis inédita).

CHAVES, R. \& SAENZ, R., 1974: Geología de la Cordillera de Tilarán (Proyecto Aguacate 2a Fase). - Dirección de Geología, Minas y Petróleo. Inf. Técn. y Not. Geol.,12 (53) 49 págs.

CHIESA, S.; CORELLA, M. \& MORA, O., 1987: Geología de la meseta ignimbrítica de Santa Rosa, Guanacaste Costa Rica. - ICE, 60 págs (unpublished report).

CONGER, P.S., 1942: Accumulation of diatomaceous deposits. - Journal of Sedimentary Petrology, 12/ 2: 55-66.

DENGO, G., 1962: Estudio geológico de la región de Guanacaste, Costa Rica. -Instituto de Geografía de Costa Rica, 112 págs.

DONDOLI, C., 1950: Liberia y sus alrededores. Boletín Técnico, Ministerio de Agricultura e Industrias $N^{\circ} 3,8$ págs.

DONDOLI, C., 1951: Zona de Palmares, estudio geoagronómico. - Boletín Técnico, Ministerio de Agricultura e Industrias $N^{\circ} 5,16$ págs.

DONDOLI, C., 1954: Estudio geológico de la región oriental de la Meseta Central. Parte 1. - IN: DONDOLI, C. \& TORRES, J. A.: Estudio geoagronómico de la región oriental de la Meseta Central. Ministerio de Agricultura e Industrias, 11-47.

GARCIA, M.V. \& ALVARADO, F., 1984: Declaración preliminar de evaluación de Impacto Ambiental. Cantera de Diatomita. - Ricalit S.A. ,66 págs., (unpublished report). 
HERD, J., 1988: Sand treatment cleans up beer. Sunday Times 8 th. May.

KADEY, F.L., 1983: Diatomite. - IN: LEFOND, S.J. (Ed.): Industrial Minerals \& Rocks. 5th. edition AIME, 677-708.

KELTS, K. \& HSƯ, K.J., 1978: Freshwater carbonate sedimentation. - IN: LERMAN, A. (Ed): Lakes, Chemistry, Geology, Physics. 295-323.,Springer-Verlag ,Berlin.

LACAYO, B. \& SOTO, G., 1978: Aspectos generales, técnicos y económicos del proyecto Diatomita. Codesa Boletín.

LOHMAN, K.E., 1960: The ubiquitous diatom a brief survey of the present state of knowledge. - American Journal of Science (Bradley Volume), 258A: 180-191.

LÖTSCHERT, W. \& MÄDLER, K., 1975: Die pliopleistozäne Flora aus dem Sisimico Tal, El Salvador. - Geol. Jb. , 13: 97-191.

LUDDINGTON, S. , CASTILLO R. \& AZUOLA, H., 1987: The geology of Costa Rica. - IN: Mineral resource assessment of the Republic of Costa Rica. Miscellaneous Investigations Series Map U.S. Geol. Survey 1」(1865): 4-7.

MADRIGAL, R., 1960: Algunas localidades con diatomita de Costa Rica. - Infor. Téc. y Not. Geol., Ministerio de Industrias (DGMP) (52. 13 págs.

MEISINGER, A.E., 1985: Diatomite, mineral facts and problems. - United States Bureau Mines.

MONTERO, W., 1975: Estratigrafía del Cenozoico del área de Turrúcares, Prov. de Alajuela, Costa Rica. - 40 págs. Escuela Centroamericana de Geología, Universidad de Costa Rica (tésis inédita).

MORA, S., 1977: Estudio geológico del Cerro Chopo. -Rev.geogr. Amer. Central,5/6: 189-199. Universidad Nacional, Heredia, Costa Rica.
MULRYAN, H., 1942: Freshwater diatomite in the Pacific Coast Region. -Trans. Am. Inst. of Mining \& Metallurgical Eng., 148: 51-58.

RODRIGUEZ, H.G., 1976: Geología de la zona sur de Palmares. - 14 págs., Escuela Centroamericana de Geología, Universidad de Costa Rica (tésis inédita).

RODRIGUEZ, H.G., 1984: Estudio técnico-geológico del área de Cantera solicitada en explotación por Ricalit S.A. (\# 1777). - Geotest S.A. 13 págs., (unpublished report).

SALAZAR, A.J., 1978: Geología de los depósitos de diatomita de las Brisas-Cañas Dulces y la Loma Camastro, Liberia, Guanacaste y su evolución preliminar. - Boletín Geológico y de Reservas Minerales (CODESA), $N^{2}$. 1: 296-319.

SANDOVAL, F., 1966: Estudio geológico y evaluación de un yacimiento de diatomita localizado en la región de Turrúcares de Alajuela. - Inf. Téc. y Not. Geol., Dirección de Geología, Minas y Petróleo, $N^{2} 23,42$ págs.

SANDOVAL, F. \& BRENES, M., 1967: Estudio geológico y evaluación de un yacimiento de diatomita localizado en la región de Montano de Bagaces de Guanacaste. - Inf. Téc. y Not. Geol. Dirección de Geología, Minas y Petróleo, № 25 , 23 págs.

SCHMIDT-THOMÉ, M., 1975: Das Diatomitvorkommen im Tal des Río Sisimico (El Salvador, Zentralamerika). - Geol. Jb., 13: 87-96.

SEGURA, A., 1940: Sección de Geología. Informe rendido a la Secretaría de Educación Pública sobre la labor realizada en 1939. - Serie de Historia del Museo, 1 (2): 48-69. Museo Nacional, San José, Costa Rica.

SEGURA, A., 1945: Rápidos apuntes sobre los mármoles de Guanacaste y otros aspectos geológicos. - Rev. Inst. Defensa del Café, 15: 337 347.

SEIFFERT, J., 1977: Fossile Frösche (Diplasiocoela Noble 1931) aus einer Kieselgur von El Salvador. - Geol. Jb., 23: 29-45. 
SERRANO, M., 1960: Descubrimiento de nuevos yacimientos de diatomita en el occidente de la República de Guatemala. - 62 págs., Universidad de San Carlos de Guatemala.

SOPER, E.K. \& OBSON, C.C., 1922: The occurrence and uses of peat in the United States. - U. S. Geological Survey Bulletin , 728.

SPRECHMANN, P.(Ed)., 1984: Manual de Geología de Costa Rica. Vol. 1: Estratigrafía. - Universidad de Costa Rica, San José ,320 págs.

TALIAFERRO, N.L., 1933: The relation of volcanism to diatomaceous and associated siliceous sedi- ments. University of California Publications. IN: Geological Science, 23: 1-55.

UMAÑA, J. ; BRUCE, E. \& MOJCA, E., 1975: Informe de reconocimiento avanzado del proyecto hidroeléctrico de Corobicí. - ICE-Dirección de Ingeniería de Energía, 32 págs.

VARGAS, J., 1976: Geología de una parte de la Hoja Naranjo (3346-111). - Escuela Centroamericana de Geología, Universidad de Costa Rica (tésis inédita).

WILLIAMSON, R., 1966: Exploration for diatomites. - Colorado School of Mines, Mineral Industries, 9/3: 1-14. 